\title{
Abdominal perfusion pressure is superior from intra-abdominal pressure to detect deterioration of renal perfusion in critically Ill patients
}

\author{
Fethi Gül, M.D., @i İsmet Sayan, M.D., @ Umut Sabri Kasapoğlu, M.D., @ Derya Özer Erol, M.D.,

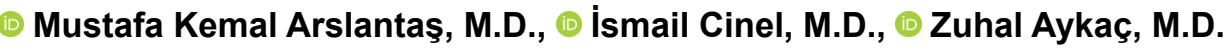

Department of Anesthesiology and Critical Care, Marmara University Pendik Training and Research Hospital, İstanbul-Turkey

\begin{abstract}
BACKGROUND: Intra-abdominal hypertension (IAH) is a frequent cause of acute kidney injury (AKI) among critically ill patients who have risk factors. This study aimed to determine the relation between Abdominal Perfusion Pressure (APP) and AKI showed by the Doppler-based renal resistive index (RRI).
\end{abstract}

METHODS: In this study, 38 patients older than 18 years old who received mechanical ventilation and had risk factors for the development of IAH were prospectively studied. All measurements and parameters were divided into two groups according to renal dysfunction (Group I: RRI <0.72 vs Group II: RRI >0.72).

RESULTS: The mean IAPs were not significant between the groups, II.5 $\pm 6.9 \mathrm{~mm} \mathrm{Hg}$ in Group I ( $\mathrm{n}=35$ ) and I3.5 \pm 5.8 in Group II $(n=33)$, respectively. APPs were statistically higher in Group I $(8 I .2 \pm 13.6)$ than Group II $(66.4 \pm 9.5)(p<0.00 I)$. The AUC for the association between APP at RRI $>0.72$ was 0.802 ( $p<0.00 \mathrm{l}$ ), with the APP $\leq 72 \mathrm{mmHg}$ having a sensitivity of the $76 \%(95 \% \mathrm{Cl} 58-89 \%)$ and a specificity of $71 \%(95 \% \mathrm{Cl} 54-85 \%)$.

CONCLUSION: Our findings suggest that an APP with a threshold of $\leq 72 \mathrm{mmHg}$ is associated with a significant increase in renal RRI, which may be predictive of worsening of renal perfusion.

Keywords: Abdominal perfusion pressure; renal perfusion pressure; renal resistive index.

\section{INTRODUCTION}

Intra-abdominal hypertension $(\mathrm{IAH})$ and abdominal compartment syndrome (ACS) have been shown to occur frequently and independently associated with morbidity and mortality among critically ill patients. ${ }^{[1]}$ Given that both of them are associated with increased morbidity and mortality, identification, avoiding, or management of these conditions may improve patient outcomes.

The intra-abdominal pressure (IAP) measurement is a key point in diagnosing and managing critically ill ICU patients who have risk factors for the development of $\mathrm{IAH}$ and ACS. ${ }^{[2]}$ IAP measurements are easy to perform and should be used routinely in daily follow ups of high-risk ICU patients. Normal IAP values are considered around $10 \mathrm{~mm} \mathrm{Hg}$ in critically ill patients. IAH has accepted an increase in IAP $\geq 12 \mathrm{mmHg}$ and ACS is defined elevation of IAP $>20 \mathrm{mmHg}$ with new onset of organ failure. Abdominal perfusion pressure (APP) is the difference between the MAP and IAP, a more accurate marker of resuscitation endpoint in patients with $\mathrm{IAH}$. The APP correlates with visceral perfusion above the $60 \mathrm{~mm} \mathrm{Hg}$ seems a good approach to maintain macro and microcirculation. ${ }^{[3]}$

An increase of the IAP can bring on several deleterious pathophysiologic consequences, which include vascular compression that reduces perfusion and venous drainage of intra-abdominal and other organs. Although mechanisms are not yet

Cite this article as: Gül F, Sayan İ, Kasapoğlu US, Erol DÖ, Arslantaş MK, Cinel İ, et al. Abdominal perfusion pressure is superior from intra-abdominal pressure to detect deterioration of renal perfusion in critically Ill patients. Ulus Travma Acil Cerrahi Derg 2019;25:561-566.

Address for correspondence: Zuhal Aykaç, M.D.

Marmara Üniversitesi Pendik Eğitim ve Araştırma Hastanesi, Anesteziyoloji ve Yoğun Bakım Kliniği, İstanbul, Turkey

Tel: +90 216 - 6254545 E-mail: aykaczuhal@hotmail.com

Ulus Travma Acil Cerrahi Derg 2019;25(6):56I-566 DOI: 10.14744/tjtes.2019.25263 Submitted: 29.06.2019 Accepted: 15.08.2019 Online: 25.10.2019

Copyright 2019 Turkish Association of Trauma and Emergency Surgery 
completely understood, systemic effects of IAP may result in life-threatening for critically ill patients. ${ }^{[4]}$ Increased IAP leads to many organ dysfunctions, mainly renal, cardiovascular, respiratory, gastrointestinal, and hepatic systems are affected.

The kidneys are more vulnerable to IAH than other organs due to the deleterious mechanical effects of the increased IAP in the blood supply. The etiology of renal dysfunction and probably one of the most important ones is diminished renal blood flow. Increment of renal vessel resistance occurs due to high IAP, which causes a decrease of microcirculatory flow in the renal cortex. This stimulates vasoconstriction of renal vessels with activation of the renin-angiotensin system that results in further diminished renal perfusion. ${ }^{[5]}$

Little evidence is known about renal monitoring during $\mathrm{IAH}$. It is a frequent cause of acute kidney injury (AKI) in ICU and not commonly recognized by an intensivist. Hence, the identification and early recognition of patients in whom renal hemodynamics deteriorate are fundamental during critical care stay for achieving good clinical outcomes. ${ }^{[6]}$ Renal resistive index (RRI), measured by renal interlobar artery Doppler ultrasonography, is a successful non-invasive bedside monitoring modality which directly reveals and quantifies modifications in renal vascular resistance. This method enables repeated assessments of the renal circulation at the bedside with high diagnostic accuracy following various therapeutic interventions in critically ill patients. ${ }^{[7]}$ It has been widely performed monitoring parameter that is gaining more frequent use in daily ICU practice. RRI values are usually obtained by translumbar or transabdominal Doppler approach, but measurements are also accessible with the transesophageal echocardiography. ${ }^{[8]} \mathrm{RRI}>0.72$ allows earlier detection of AKI before other biochemical parameters increase, such as creatinine. Thus, careful fluid management and hemodynamic adjustments with avoiding the use of nephrotoxic medication are possible. ${ }^{[9]}$

The primary purpose of this prospective single-center study was to investigate the relationship between APP and AKI showed by Doppler-based RRI. The secondary goal was to examine the correlation between the clinical and laboratory characteristics of the patients who had this pathologic condition.

\section{MATERIALS AND METHODS}

\section{Data Collection}

Age, gender, APACHE II (Acute Physiology and Chronic Health Evaluation) and SOFA (Sequential Organ Failure Assessment) scores were recorded. Simultaneous IAP, APP, Mean Arterial Pressure (MAP), cardiac output, cardiac index, heart rate, serum creatinine, lactate levels, mechanic ventilatory parameters; positive end-expiratory pressure (PEEP), Ppeak, $\mathrm{FiO}_{2}$ and $\mathrm{PaO}_{2}$ which were measured with arterial blood sampling $\left(\mathrm{PaO}_{2} / \mathrm{FiO}_{2}[\mathrm{PF}]\right.$ ratio) at baseline and at $24^{\text {th }}$ hours were noted.

\section{Patient Population}

This prospective study was conducted between March 2018 to March 2019 in the Intensive Care Unit of the Marmara University Pendik Education and Research Hospital. The Clinical Research Ethics Committee of the Marmara University approved the study (registration number: 09.2018.105). All participants or legal representatives signed an Informed Consent Form.

In total, 38 mechanically ventilated with deep sedation (6 points on the Ramsay scale) ICU patients (>I8 years old) who had risk factors for the development of $\mathrm{IAH}$ and ACS and expected to stay $>24 \mathrm{~h}$ were included in this study. Exclusion criteria consisted of pregnancy, heart failure, non-sinus cardiac rhythm that affected renal resistive index, chronic renal failure or renal artery disease (unilateral kidney, renal stone disease, renal artery stenosis or having a contraindication for intravesical pressure measurement, eg. pelvic fracture, hematuria, or neurogenic bladder).

$\mathrm{RRI} \geq 0.72$ has been considered as a marker of renal dysfunction and acute kidney injury. ${ }^{[9]}$ We divided all measurements into two groups, according to RRI. RRI $<0.72$ measurements were grouped as Group I $(n=35)$. Group II $(n=33)$ measurements included RRI above $>0.72$.

According to the Consensus definitions of the WSACS (www. wsacs.org), IAH is defined by the sustained or repeated elevation of IAP > $12 \mathrm{mmHg}$. Abdominal perfusion pressure (APP) was calculated by subtracting the IAP from the mean arterial pressure (MAP): APP=MAP-IAP. ${ }^{[3]}$

\section{IAP Measurement Techniques}

The intra-vesicular pressure was measured through a closedsystem Foley bladder catheter. It was measured at the end of the expiration with the patient in the supine position and the transducer placed at the mid-axillary line where it crosses the iliac crest. A transducer-based needle with an interposition T-piece was used directly to canulate the urinary catheter directly. The transducer (Pressure Set, Sasan Medical Disposable Products, Ankara, Turkey) was used to connect the system to bedside monitor (IntelliVue MX550, Philips Healthcare, Inc., Andover, MA, USA). The urinary drainage tube was clamped and a maximum of $25 \mathrm{~mL}$ of saline was instilled into the bladder through a foley catheter. Then, zero pressure on the monitor was achieved. IAP was measured on the monitor with stopcocks open to a pressure transducer, after a one-minute equilibration period. To the extent possible, the IAP was measured twice a day (basal and then at $24 \mathrm{~h}$ ).

\section{RRI and Cardiac Output (CO) Measurements}

RRI measurements were performed using a Philips EPIQ 7 ultrasound system (Philips Healthcare, Inc., Andover, MA, USA) by a trained intensivist who is certified in ultrasonography. 
Renal Doppler was performed on the interlobar arteries using a convex probe. Renal vasculature was identified using color Doppler, and then, the arterial waveforms were obtained by Doppler in the interlobar renal artery. RRI at the interlobular or arcuate artery near the border of the central echo complex was measured three times in the upper, middle, and lower portions of the kidney. In each patient, the following formula was used to calculate RI: (RRI = [peak systolic velocity - end-diastolic velocity]/peak systolic velocity). Three measurements were performed and the mean value of three measurements at each kidney calculated. ${ }^{[8]}$

Non-invasive Ultrasonic Cardiac Output Monitor (USCOM; USCOM Ltd., Sydney, Australia, 2005) was used to measure cardiac output transcutaneously via a probe applied to the suprasternal notch.

\section{Statistical Analysis}

Continuous parametric and nonparametric variables were presented as the mean (standard deviation) and median (25th; 75th percentiles) and were compared using the t-test and Mann-Whitney test, respectively. Categorical variables were expressed as absolute ( $n$ ) and relative (\%) frequency and were compared by the Chi-square test. The normality of variables was tested using the Shapiro-Wilk test for normality. Receiver operating characteristic curves were generated to test the predictive discrimination threshold of impaired renal perfusion (RRI $\geq 0.72$ ) and normal renal perfusion (RRI $<0.72$ ) to APP. The area under the ROC curve (AUC) was calculated and compared using a Hanley- McNeil test. The optimal threshold value (the value that maximizes the sum of the sensitivity and specificity) was also defined for APP. The criterion associated with the Youden index is reported with its $95 \% \mathrm{Cl}$ based on bootstrapping using 1000 replications. The sensitivity and specificity values are also reported with the $95 \% \mathrm{Cl}$. Significance was assumed for a two-sided $\mathrm{p}$-value $<0.05$. All statistical analyses were performed using SPSS 2 I (IBM SPSS Statistics, Chicago, IL, USA) and MedCalc 14 software (MedCalc, Mariakerke, Belgium). For all comparisons, a $\mathrm{p}$-value of less than 0.05 was considered significant.

\section{RESULTS}

We enrolled 38 patients ( 17 female) fulfilling inclusion/exclusion criteria. In total, 68 IAP and RRI measurements were performed. Heart rate, cardiac output, cardiac index, P/F ratio, PEEP, Ppeak, lactate levels, $\mathrm{pH}$ and $\mathrm{SpO}_{2}$ levels were comparable between the groups. The patients' clinical and laboratory parameters are reported in Table I. In addition to this, the characteristics and diagnosis of the patients at inclusion who had risk factors for the development of IAH and ACS are shown in Table 2.

The mean of IAPs were not significant between the groups [ I $1.5 \pm 6.9 \mathrm{mmHg}$ in Group I $(\mathrm{n}=35)$ vs 13.5 \pm 5.8 in Group II
Table I. Comparison of clinical and laboratory characteristics with and without acute kidney injury

\begin{tabular}{lccc}
\hline & $\begin{array}{c}\text { Group I } \\
(\mathbf{n}=35)\end{array}$ & $\begin{array}{c}\text { Group II } \\
(\mathbf{n}=33)\end{array}$ & $\mathbf{p}$ \\
\hline $\mathrm{IAP}(\mathrm{mmHg})$ & $11.5 \pm 6.9$ & $13.5 \pm 5.8$ & 0.184 \\
$\mathrm{MAP}(\mathrm{mmHg})$ & $93 \pm 13$ & $80 \pm 9$ & $<0.001$ \\
APP $(\mathrm{mmHg})$ & $81.2 \pm 13.6$ & $66.4 \pm 9.5$ & $<0.001$ \\
Heart rate $(\mathrm{bpm})$ & $95 \pm 18$ & $97 \pm 14$ & 0.692 \\
Cardiac output $(\mathrm{L} / \mathrm{min})$ & $4.9 \pm 1.7$ & $4.0 \pm 1.7$ & 0.054 \\
Cardiac index $\left(\mathrm{L} / \mathrm{min} / \mathrm{m}^{2}\right)$ & $2.4 \pm 0.9$ & $2.3 \pm 1.2$ & 0.415 \\
P/F ratio & $302 \pm 99$ & $340 \pm 189$ & 0.309 \\
PEEP $\left(\mathrm{cmH}{ }_{2} \mathrm{O}\right)$ & $6.6 \pm 1.8$ & $7.2 \pm 2.1$ & 0.173 \\
Ppeak $\left(\mathrm{cmH}_{2} \mathrm{O}\right)$ & $26.8 \pm 6.1$ & $27.2 \pm 7.1$ & 0.812 \\
SpO ${ }_{2}(\%)$ & $97.7 \pm 1.9$ & $98.8 \pm 1.9$ & 0.058 \\
Serum creatinin $(\mathrm{mg} / \mathrm{dL})$ & $1.12 \pm 0.9$ & $1.78 \pm 1.23$ & 0.029 \\
Ph & $7.44 \pm 0.07$ & $7.41 \pm 0.09$ & 0.111 \\
Lactate $\left(\mathrm{mmol}^{2} \mathrm{~L}\right)$ & $1.78 \pm 1.39$ & $2.47 \pm 2.52$ & 0.170 \\
Renal resistive index & $0.66 \pm 0.05$ & $0.80 \pm 0.05$ & $<0.001$ \\
\hline
\end{tabular}

IAP: Intrabdominal pressure; MAP: Mean arterial pressure; APP: Abdominal perfusion pressure; PEEP: Positive end-expiratory pressure.

Table 2. Characteristics and diagnosis at the inclusion of the 38 patients who had risk factors for the development of IAH and ACS

\begin{tabular}{lc}
\hline Parameter & Value \\
\hline Age, (years) & $55.3 \pm 17.7$ \\
Sex, $\mathrm{n}(\%)$ & 21 (55\%) \\
$\quad$ Male & $17(45 \%)$ \\
$\quad$ Female & $20.3 \pm 8.4$ \\
APACHE II (inclusion) & $8(5-10)$ \\
SOFA (inclusion) & \\
Diagnosis (n) & 10 \\
$\quad$ Intrabdominal sepsis & 7 \\
$\quad$ Pneumonia sepsis & 7 \\
Intracerebral hemorrhage & 2 \\
Pancreatitis & 2 \\
$\quad$ Hepatic encephalopathy & 3 \\
Acute myocardial infarction & 3 \\
Intraabdominal tumor & 4 \\
Others & \\
\hline
\end{tabular}

The data are presented as mean \pm standard deviation, median [interquartile range: P25 to P75] or count (percentage). APACHE II: Acute Physiology and Chronic Health Evaluation II; SOFA: Sequential Organ Failure Assessment.

$(n=33)]$. MAP measurements were higher in Group I $(93 \pm 13$ $\mathrm{mmHg})$ compared to Group II $(80 \pm 9 \mathrm{mmHg})(\mathrm{p}<0.001)$. A significant difference in APP measurements was found between 


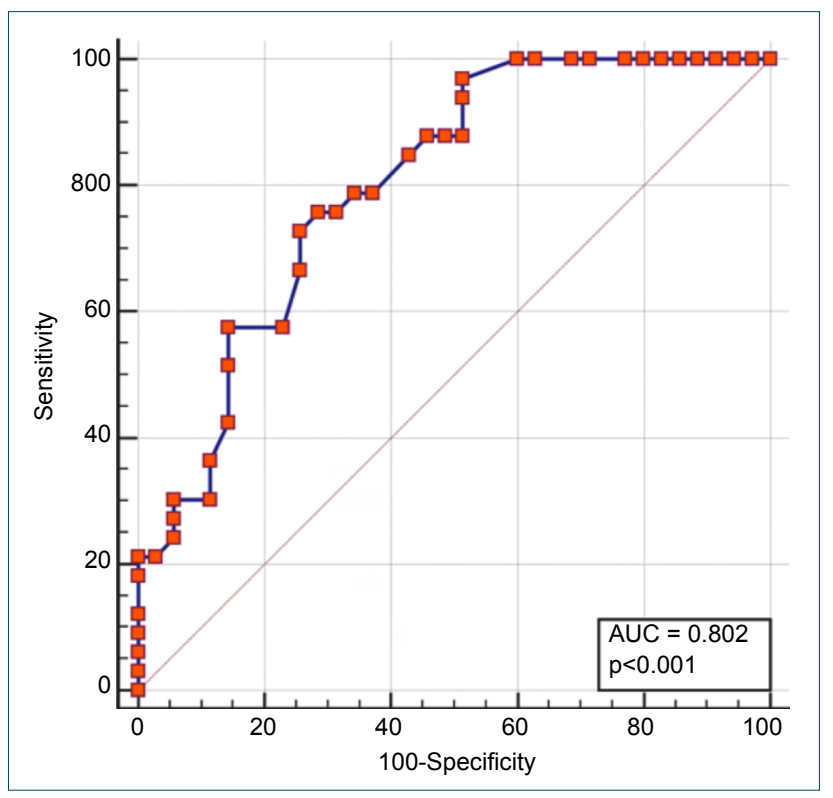

Figure 1. Receiver operating characteristic (ROC) curve for the association between the Abdominal Perfusion Pressure (APP) and an increased renal resistive index (>0.72). AUC: The area under of a ROC curve.

the groups. APPs were statistically higher in Group I than

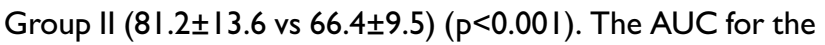
association between APP at RRI >0.72 was $0.802(p<0.00 I)$, with the APP $\leq 72 \mathrm{mmHg}$ having a sensitivity of $76 \%(95 \% \mathrm{Cl}$ $58-89 \%)$ and a specificity of $71 \%$ (95\% Cl 54-85\%) (Fig. I).

The serum creatinine levels were significantly higher in patients in Group II compared to Group I (I.I $2 \pm 0.9$ vs $\mathrm{I} .78 \pm \mathrm{I} .23)(\mathrm{p}=0.029)$.

\section{DISCUSSION}

The principal finding of this study showed that an APP with a $\leq 72 \mathrm{mmHg}$ threshold is associated with a significant increase in renal RRI. Thus Doppler ultrasonography with RRI calculation can be a useful method in managing these patients to determine the optimal APP level for renal perfusion. Our findings also suggest that the increase of this index represents renal impairment is possible although IAP is normal. An APP value $\leq 72 \mathrm{mmHg}$ was the best cut-off for renal dysfunction prediction and a more reliable parameter than IAP. Thus, this threshold suggests that the kidney is a potential organ for adverse physiologic effects, so prompting intervention at an earlier stage should be started. In this study, we also reported significantly elevated creatinine levels concurrently together with the increasing levels of RRI. As such, early accurate assessment of renal dysfunction radiologically with RRI is possible and maybe essential in restoring kidney perfusion during the deterioration of APP.

$\mathrm{IAH}$ is an independent cause of mortality and very common in critically ill patients. ${ }^{[10]}$ IAP exerts deleterious effects on various organs. Thus, accurate assessment and lowering of
IAP and establishing sufficient abdominal perfusion pressure appear essential strategies to maintain end-organ perfusion. $\mathrm{IAH}$ hypothetically directly or indirectly impairs nearly every organ system and is life-threatening for the critically ill patients, but the link between IAH and organ dysfunctions are not yet completely understood. Increased pressure may lead to compromised organ perfusion. For instance, cardiac contractility and ventricular function may decrease dramatically by reducing the preload of the heart. The presence of IAH is associated with an increase of intrathoracic pressures, and proportionally peak and plateau airway pressures. Transmission of abdominal pressures to the thoracic cavity may affect mainly respiratory mechanics. ${ }^{[1,12]}$ Augmented airway pressures are necessary to overcome resistance in the airway due to increased rigidity of the thoracic wall. In addition to this, it was proposed that patients having a peak airway pressure $>28 \mathrm{~cm} \mathrm{H}_{2} \mathrm{O}$ are more likely to have IAH. ${ }^{[13]}$ The hypoxemia and hypercapnia may occur as a result of mechanic compression of the lungs. Impair perfusion of the liver may result in elevated serum lactate levels, and it may also give rise to the disturbance of cerebral perfusion. ${ }^{[14]}$

The APP is a new parameter that shows the circulatory compromise in the abdominal cavity. The APP appears as a better resuscitation endpoint compared to other macro and microcirculatory parameters and recommended by the current literature. ${ }^{[15]}$ More importantly, it is associated with visceral perfusion instead of IAP alone if feasible and has sensitivity for decision making. Evidence suggested that it is superior to IAP or other hemodynamic parameters to predict mortality. ${ }^{[16]}$ A study found that APP is better than MAP and lactate to discriminate survivors from nonsurvivors. ${ }^{[17]}$ As APP $<60$ $\mathrm{mmHg}$ was considered as an indicator of abdominal hypoperfusion, ${ }^{[18]}$ but at which APP early renal impairment occurs, radiologically remains unclear. In our study, the cut-off point APP $\leq 72 \mathrm{mmHg}$ was found to be an indicator of early renal hypoperfusion because at this pressure, a significant increase in RRI was observed.

The adverse influence of IAH on renal function is often unappreciated by clinicians given that $\mathrm{IAH}$ is an independent cause of renal dysfunction. ${ }^{[19]}$ Some new data claim that kidneys are particularly at high risk, and renal dysfunction occurs with much lower levels of IAP among critically ill patients. ${ }^{[20]}$ IAH is still the cause of or contributing factor in AKI. Hence, in the early time, to find the etiology and management of critically ill patients with raised IAP should be concerned to prevent and avoid progression. IAH is associated with many negative effects on the kidneys that arise from multiple factors. It assumes that two main mechanisms during increased IAP, indirectly (systemic effects) or directly (renal effects), may affect kidney function. ${ }^{[21]}$

The kidneys are physiologically at risk of IAH mainly due to its susceptibility vasculature nature, but mechanisms underlying the vulnerability are not fully known. ${ }^{[22]}$ The mechanisms 
involved in the pathophysiology are complex, and one of the most consistently described effects is related to renal blood flow. It was suggested that renal vein compression with renal artery vasoconstriction seems to be the major cause of renal impairment. ${ }^{[5]}$ In addition, direct compression of the renal cortex results in a decrease in blood flow. A large prospective observational study established IAH and low APP resulted as the best predictive factors for ARF. ${ }^{[23]}$ Some studies concluded that an IAP I5-20 mmHg causes in oliguriaand anuria develops above $30 \mathrm{mmHg}{ }^{[24]}$ Besides, the rate of renal impairment can be raised according to the level of IAP; the incidence is doubling at $25 \mathrm{mmHg}$ compared to $18 \mathrm{mmHg}$. ${ }^{[19]}$ Moreover, Dalfino et al. ${ }^{[23]}$ demonstrated that an association between IAH and acute kidney injury (AKI) in unselected ICU patients, IAH was a good predictor of AKI. It has also has been suggested that there is a clear link between IAH and the development of AKI in the kidney transplant patient. Early transplant dysfunction was treated using abdominal decompression in those patients. ${ }^{[25]}$ However, in our study, we showed that elevated RRI and high levels of creatinine are possible with normal IAP.

Despite increasing interest in the use of ultrasound in critically ill patients, there has been a little report in the clinical examination of the patient with IAH. There are very limited data concerning aiming ideal APP to prevent acute kidney injury, and there is little evidence of radiologic measurement to show these subtle forms of organ dysfunction during IAH. RRI has been used for years in a variety of clinical settings, especially became apparent to differentiate acute and chronic obstructive renal disease. RRI provides useful information about changes in intrarenal perfusion and has been proposed to monitor renal perfusion in critically ill patients. ${ }^{[8,26,27]}$ It was shown that this index might be affected by IAH and allowed earlier detection of renal impairment before the increase of other biochemical parameters. ${ }^{[9]}$ In a porcine model, it was demonstrated that a linear relationship between increasing IAP and RRI and the author concluded that it might be a potential noninvasive, bedside screening tool to detect early deterioration of renal perfusion. ${ }^{[28]}$ In 45 healthy volunteers, a mild increase in IAP compresses the major abdominal vessels was associated with a significant increase in RRI, suggesting that even mild IAH may affect intrarenal pressure. ${ }^{[5]}$ However, in our study, the cut-off point of APP $\leq 72 \mathrm{mmHg}$ is associated with a statistically significant increase of RRI suggesting that supporting renal function to maintain an APP $>72 \mathrm{mmHg}$ is to be advocated. Our findings suggest that an ideal APP determination is important and may be useful to prevent acute kidney injury.

\section{Conclusion}

Kidneys seem to be the most susceptible organ to the adverse consequences of increased IAP. Increased RRI may be a useful index for objective evidence of impending kidney injury that occurs before other end-organ dysfunctions. The results of our study show that an APP with a threshold of $\leq 72 \mathrm{mmHg}$ is associated with a significant increase in renal $\mathrm{RRI}$, which is predictive of worsening of renal perfusion. More importantly, our results suggest that kidneys may be particularly at risk with much higher levels of APP than believed previously. Measuring RRI using a noninvasive bedside renal Doppler ultrasound is a valuable tool to detect deterioration of renal perfusion, considering the importance of APP. In conclusion, it has an active role in helping to prevent potentially fatal complications of IAH/ACS and should be integrated while treating critically ill patients who have risk factors.

\section{Conflict of interest: None declared.}

\section{REFERENCES}

1. Balogh Z, McKinley BA, Cocanour CS, Kozar RA, Valdivia A, Sailors $\mathrm{RM}$, et al. Supranormal trauma resuscitation causes more cases of abdominal compartment syndrome. Arch Surg 2003;138:637-42. [CrossRef]

2. Malbrain ML, De laet IE. Intra-abdominal hypertension: evolving concepts. Clin Chest Med 2009;30:45-70. [CrossRef]

3. Kirkpatrick AW, Roberts DJ, De Waele J, Jaeschke R, Malbrain ML, De Keulenaer B, et al. Intra-abdominal hypertension and the abdominal compartment syndrome: updated consensus definitions and clinical practice guidelines from the World Society of the Abdominal Compartment Syndrome. Intensive Care Med 2013;39:1190-206. [CrossRef]

4. de Laet IE, Malbrain M. Current insights in intra-abdominal hypertension and abdominal compartment syndrome. Med Intensiva 2007;31:88-99.

5. Cavaliere F, Cina A, Biasucci D, Costa R, Soave M, Gargaruti R, et al. Sonographic assessment of abdominal vein dimensional and hemodynamic changes induced in human volunteers by a model of abdominal hypertension. Crit Care Med 2011;39:344-8. [CrossRef]

6. Joannidis M, Druml W, Forni LG, Groeneveld ABJ, Honore PM, Hoste $\mathrm{E}$, et al. Prevention of acute kidney injury and protection of renal function in the intensive care unit: update 2017 : Expert opinion of the Working Group on Prevention, AKI section, European Society of Intensive Care Medicine. Intensive Care Med 2017;43:730-49. [CrossRef]

7. Barozzi L, Valentino M, Santoro A, Mancini E, Pavlica P. Renal ultrasonography in critically ill patients. Crit Care Med 2007;35:S198-205.

8. Kararmaz A, Kemal Arslantas M, Cinel I. Renal Resistive Index Measurement by Transesophageal Echocardiography: Comparison With Translumbar Ultrasonography and Relation to Acute Kidney Injury. J Cardiothorac Vasc Anesth 2015;29:875-80. [CrossRef]

9. Marty P, Szatjnic S, Ferre F, Conil JM, Mayeur N, Fourcade O, et al. Doppler renal resistive index for early detection of acute kidney injury after major orthopaedic surgery: a prospective observational study. Eur J Anaesthesiol 2015;32:37-43. [CrossRef]

10. Reintam A, Parm P, Kitus R, Kern H, Starkopf J. Primary and secondary intra-abdominal hypertension--different impact on ICU outcome. Intensive Care Med 2008;34:1624-31. [CrossRef]

11. Malbrain ML, Roberts DJ, Sugrue M, De Keulenaer BL, Ivatury R, Pelosi P, et al. The polycompartment syndrome: a concise state-of-the-art review. Anaesthesiol Intensive Ther 2014;46:433-50. [CrossRef]

12. Regli A, Chakera J, De Keulenaer BL, Roberts B, Noffsinger B, Singh B, et al. Matching positive end-expiratory pressure to intra-abdominal pressure prevents end-expiratory lung volume decline in a pig model of intraabdominal hypertension. Crit Care Med 2012;40:1879-86. [CrossRef]

13. Reintam BA, Parm P, Kitus R, Starkopf J. Risk factors for intraabdom- 
inal hypertension in mechanically ventilated patients. Acta Anaesthesiol Scand 2011;55:607-14. [CrossRef]

14. Carr JA. Abdominal compartment syndrome: a decade of progress. J Am Coll Surg 2013;216:135-46. [CrossRef]

15. Malbrain ML, Cheatham ML, Kirkpatrick A, Sugrue M, Parr M, De Waele J, et al. Results from the international conference of experts on intra-abdominal hypertension and abdominal compartment syndrome. I. Definitions. Intensive Care Med 2006;32:1722-32. [CrossRef]

16. Vidal MG, RuizWeisser J, Gonzalez F, Toro MA, Loudet C, Balasini $\mathrm{C}$, et al. Incidence and clinical effects of intra-abdominal hypertension in critically ill patients. Crit Care Med 2008;36:1823-31. [CrossRef]

17. Cheatham ML, White MW, Sagraves SG, Johnson JL, Block EF. Abdominal perfusion pressure: a superior parameter in the assessment of intraabdominal hypertension. J Trauma 2000;49:621-7. [CrossRef]

18. Rezende-Neto JB, Moore EE, Melo de Andrade MV, Teixeira MM, Lisboa FA, Arantes RM, et al. Systemic inflammatory response secondary to abdominal compartment syndrome: stage for multiple organ failure. J Trauma 2002;53:1121-8. [CrossRef]

19. Sugrue M, Jones F, Deane SA, Bishop G, Bauman A, Hillman K. Intraabdominal hypertension is an independent cause of postoperative renal impairment. Arch Surg 1999;134:1082-5. [CrossRef]

20. Mullens W, Abrahams Z, Skouri HN, Francis GS, Taylor DO, Starling $\mathrm{RC}$, et al. Elevated intra-abdominal pressure in acute decompensated heart failure: A potential contributor to worsening renal function? J Am
Coll Cardiol 2008;51:300-6.

21. Cheatham ML. Abdominal compartment syndrome: Pathophysiology and definitions. Scand J Trauma Resusc Emerg Med 2009;17:10. [CrossRef]

22. Guyton AC, editor. Formation of urine by the kidney: I. Renal blood flow, glomerular filtration, and their control. In: Textbook of Medical Physiology. 8th ed. Philadelphia:WB Saunders; 1991. p. 286-307.

23. Dalfino L, Tullo L, Donadio I, Malcangi V, Brienza N. Intra-abdominal hypertension and acute renal failure in critically ill patients. Intensive Care Med 2008;34:707-13. [CrossRef]

24. Cheatham ML. Abdominal compartment syndrome: Pathophysiology and definitions. Scand J Trauma Resusc Emerg Med 2009;17:10. [CrossRef]

25. Pertek JP, Coissard A, Lalot JM, Renoult E, Cormier L. Hypoperfused kidney following kidney transplantation associated with hyperlactatemia. Ann Fr Anest Reanim 2001;20:282-8. [CrossRef]

26. Izumi M, Sugiura T, Nakamura H, Nagatoya K, Imai E, Hori M. Differential diagnosis of prerenal azotemia from acute tubular necrosis and prediction of recovery by Doppler ultrasound. Am J Kidney Dis 2000;35:713-9. [CrossRef]

27. Stevens PE, Gwyther SJ, Hanson ME, Boultbee JE, Kox WJ, Phillips ME. Noninvasive monitoring of renal blood flow characteristics during acute renal failure in man. Intensive Care Med 1990;16:153-8. [CrossRef]

28. Kirkpatrick AW, Colistro R, Laupland KB, Fox DL, Konkin DE, Kock $\mathrm{V}$, et al. Renal arterial resistive index response to intraabdominal hypertension in a porcine model. Crit Care Med 2007;35:207-13. [CrossRef]

\section{ORİIINAL ÇALIŞMA - ÖZET}

\section{Kritik hastalarda abdominal perfüzyon basıncı renal perfüzyondaki bozulmanın saptanmasında karıniçi basınçtan daha üstündür}

\section{Dr. Fethi Gül, Dr. İsmet Sayan, Dr. Umut Sabri Kasapoğlu, Dr. Derya Özer Erol, Dr. Mustafa Kemal Arslantaş, Dr. İsmail Cinel, Dr. Zuhal Aykaç}

Marmara Üniversitesi Pendik Eğitim ve Araştırma Hastanesi, Anesteziyoloji ve Yoğun Bakım Kliniği, İstanbul

AMAÇ: Karıniçi hipertansiyon (KH) risk faktörü olan kritik hastalarda akut böbrek hasarının (AKI) en sık nedenlerinden biridir. Bu çalışmada abdominal perfüzyon basıncı (APP) ile Doppler temelli renal rezistif indeks (RRI) ile gösterilen AKI arasındaki ilişkiyi saptamayı amaçladık.

GEREÇ VE YÖNTEM: Bu çalışmaya KH için risk faktörü taşıyan ve mekanik ventilasyon desteği altında 18 yaşından büyük 38 hasta alındı. Tüm ölçümler ve elde edilen parametreler renal disfonksiyona göre iki gruba ayrıldı (Grup I; RRI <0.72 ve Grup II; RRI >0.72).

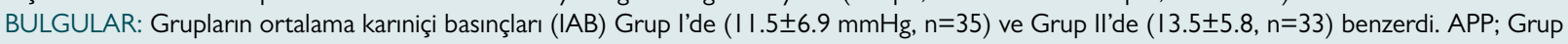
I'de (8I.2 \pm I3.6) Group Il'ye göre (66.4 \pm 9.5$)$ daha yüksekti ( $p<0.00 \mathrm{I})$. RRl'ya göre renal perfüzyondaki bozulma APP'nin $(\leq 72 \mathrm{mmHg})$ belirlemdeki duyarlıı̆ı \%76 ve seçiciliği \%7l'dir. ROC eğrisi altında kalan alan 0.802'dir $(p<0.001)$.

TARTIŞMA: Çalışmamızın sonuçları APP $\leq 72 \mathrm{mmHg}$ eşik değerinde RRI'nın anlamlı şekilde arttı̆̆ını ve bunun da renal perfüzyonun bozulmasını öngörebileceğini göstermiştir.

Anahtar sözcükler: Abdominal perfüzyon basıncl; renal perfüzyon basıncı; renal resistif indeks.

Ulus Travma Acil Cerrahi Derg 2019;25(6):561-566 doi: 10.14744/tites.2019.25263 